\title{
Fibroblast growth factor signalling induces loss of progesterone receptor in breast cancer cells
}

\author{
Dominika Piasecka ${ }^{1,4}$, Kamila Kitowska ${ }^{1}$, Dominika Czaplinska², Kamil Mieczkowski ${ }^{1}$, \\ Magdalena Mieszkowska ${ }^{1}$, Lukasz Turczyk1 ${ }^{1}$, Andrzej C. Skladanowski', Anna J. \\ Zaczek $^{2}$, Wojciech Biernat ${ }^{3}$, Radzislaw Kordek ${ }^{4}$, Hanna M. Romanska ${ }^{4}$, Rafal Sadej ${ }^{1}$ \\ ${ }^{1}$ Department of Molecular Enzymology, Intercollegiate Faculty of Biotechnology, University of Gdansk and Medical University \\ of Gdansk, Poland \\ ${ }^{2}$ Department of Cell Biology, Intercollegiate Faculty of Biotechnology, University of Gdansk and Medical University of Gdansk, \\ Poland \\ ${ }^{3}$ Department of Pathomorphology, Medical University of Gdansk, Poland \\ ${ }^{4}$ Department of Pathology, Medical University of Lodz, Poland \\ Correspondence to: Rafal Sadej, email: rsadej@gumed.edu.pl \\ Hanna M. Romanska, email: hanna.romanska@gmail.com
}

Keywords: progesterone receptor, FGFR2, breast cancer

Received: April 12, $2016 \quad$ Accepted: November 07, $2016 \quad$ Published: November 12, 2016

\section{ABSTRACT}

We have recently demonstrated that, fibroblast growth factor 2 (FGFR2), signalling via ribosomal $\mathbf{S 6}$ kinase 2 (RSK2), promotes progression of breast cancer (BCa). Loss of progesterone receptor (PR), whose activity in BCa cells can be stimulated by growth factor receptors (GFRs), is associated with poor patient outcome. Here we showed that FGF7/FGFR2 triggered phosphorylation of PR at Ser294, PR ubiquitination and subsequent receptor's degradation via the 265 proteasome pathway in BCa cells. We further demonstrated that RSK2 mediated FGF7/FGFR2-induced PR downregulation. In addition, a strong synergistic effect of FGF7 and progesterone (Pg), reflected in the enhanced anchorage-independent growth and cell migration, was observed. Analysis of clinical material demonstrated that expression of PR inversely correlated with activated RSK (RSK-P) ( $p=0.016)$. Patients with RSK-P(+)/PR(-) tumours had 3.629-fold higher risk of recurrence $(p=0.002)$, when compared with the rest of the cohort. Moreover, RSK-P(+)/PR(-) phenotype was shown as an independent prognostic factor $(p=0.006)$. These results indicate that the FGF7/FGFR2-RSK2 axis promotes PR turnover and activity, which may sensitize BCa cells to stromal stimuli and contribute to the progression toward steroid hormone negative $\mathrm{BCa}$.

\section{INTRODUCTION}

Progesterone receptor (PR), a ligand-activated transcription factor, belongs to the steroid hormone receptor family. Although it is encoded by a single gene $(P G R)$, differential transcription, followed by translation from two alternative initiation codons, results in expression of two isoforms of the PR protein: PR A (90 kDa) and PR B (116 kDa) [1]. As demonstrated in rodents, a ratio of $\mathrm{PR} A / \mathrm{PR} \mathrm{B}$ expression is a key biological determinant of tissue responsiveness to ligand stimuli and it is a critical regulator of lobuloalveolar development of the mammary gland [2-4]. An involvement of PR in the initiation and progression of breast carcinoma (BCa) is indubitable [2], but the molecular mechanism of its action is complex and still remains poorly understood. An increased incidence of $\mathrm{BCa}$ in women taking both estrogen and progestins (synthetic ligands of progesterone $(\mathrm{Pg})$ ) for hormone replacement therapy, compared to estrogen alone [5], gives support to the impact of PR-mediated signalling on $\mathrm{BCa}$ pathophysiology. $\mathrm{ER}(+) / \mathrm{PR}(+)$ tumours represent approximately $50-70 \%$ of all $\mathrm{BCa}$ cases, and PR loss is associated with resistance to hormonal therapy and increased tumour invasiveness [6], which is corroborated by numerous reports of substantially poorer outcome of patients with $\mathrm{ER}(+) / \mathrm{PR}(-)$ tumours following tamoxifenbased treatment [7-10]. 
There are two types of PR signalling pathways: a classical (genomic), involving PR action in regulation of target gene expression, and an alternative (nongenomic), in which PR does not directly participate in gene transcription. In the classical pathway, upon ligand binding, cytoplasmic PR translocates to the nucleus and triggers expression of genes with the PRE (progesterone response element) sequence [11]. PR takes part in a large number of alternative, non-genomic signalling cascades in which PR activates MAPK and PI3K/AKT pathways rapidly initiating various cellular events (e.g. cell migration, adhesion, proliferation) or expression of related genes (MSX2, RGS2, PDK4) [12-15]. PR is highly post-translationally modified including phosphorylation, sumoylation, acetylation or ubiquitination $[16,17]$. These modifications are frequently ligand-dependent but they might also occur independently of ligand-binding, for example, in response to kinases activity. PR modifications significantly alter receptor's stability, localization, transcriptional activity and promoter selectivity [18].

The mechanisms underlying acquisition of hormone independence by breast cancer cells still remain elusive. It is well recognised that reciprocal interactions between tumour cells and stromal microenvironment play a key role in cancer development. In particular, cancer-associated fibroblasts (CAFs) are considered to be crucial for tumour progression and metastasis [19]. By secretion of soluble factors such as transforming growth factor $\beta$ (TGF- $\beta$ ), insulin-like growth factor-1 (IGF-1), stroma-derived factor 1 (SDF-1), or fibroblast growth factors (FGFs), CAFs promote tumour angiogenesis and increase invasiveness of cancer cells [20-22]. As demonstrated by Giulianelli et al., CAFs activate PR through paracrine action of FGF2, which induces hormone independent mammary tumour growth [23]. PR has so far been shown to be activated by growth factors (GFs) such as IGF-1 [24], epidermal growth factor (EGF) [16] and FGF2 [25]. Reciprocal interactions between PR- and growth factor receptors (GFR)-mediated signalling result in progesterone-independent activation of PR as well as PR-regulated GFR expression and function $[25,26]$. Several studies demonstrated that activation of PR by phosphorylation at Ser294 is followed by nuclear localization and further receptor's degradation [18, 27-29]. This sequence is thought to be initiated by growth factors-triggered signalling, promoting generation of a pool of hypersensitive PR forms responsive to very low concentrations of the ligand [24].

Herein we showed for the first time that in MCF7, T47D and BT474 breast cancer cell lines, phosphorylation of PR at Ser294 and subsequent downregulation of PR protein level was induced by FGF7/FGFR2 (fibroblast growth receptor 2)-triggered signalling. Inhibition of proteasome 26S prevented FGF7-dependent PR downregulation suggesting that FGF7 signalling had led to PR proteolysis through the ubiquitin-related pathway. Furthermore, we showed that ribosomal S6 kinase 2 (RSK2) mediated FGF7/FGFR2-triggered PR downregulation in MCF7 cells. Analysis of clinical material demonstrated that expression of PR inversely correlated with activated RSK (RSK-P), thus confirming in vitro findings. Moreover, patients with $\mathrm{RSK}-\mathrm{P}(+) / \mathrm{PR}(-)$ tumours had worse disease-free survival (DFS) when compared to the rest of the cohort. In addition, FGF7 has been found to potentiate PR-dependent growth and migration of MCF7 cells. These results, together with our recently reported findings demonstrating that lack of combined immunoreactivity for FGFR2 and activated RSK (RSK-P) was predictive of a better patients' DFS [30] suggest that FGF7/FGFR2 induces degradation and activity of PR which may contribute to microenvironmentdriven shift of breast cancer cells towards hormone independence.

\section{RESULTS}

\section{FGF7/FGFR2 action downregulates PR}

A cross-talk between FGFR2 and PR signalling and a nuclear interaction between FGFR-2 and PR in breast cancer cells have already been reported [25]. It has also been demonstrated that activity of various growth factors (e.g. EGF, IGF-1, heregulin) may affect PR protein and/or mRNA levels $[24,26,31]$. Herein we found that prolonged treatment $(48 \mathrm{~h})$ of MCF7 BCa cells with various FGFs (FGF1, FGF2, FGF4, FGF6, FGF7 and FGF9) downregulated levels of both PR isoforms (Figure 1A). Since PR A and PR B were equally responsive to the treatment with FGFs (no change in the PR A: PR B ratio was observed), hereafter PR will refer to both isoforms. All tested FGFs affected PR expression. The strongest effect was observed for FGF1, FGF4 and FGF7 (all at $50 \mathrm{ng} / \mathrm{ml}$ ). Based on this result and published evidence of a role of FGF7 in both physiology and carcinogenesis of the mammary gland [32-34] FGF7 was used for further experiments. An impact of FGF7 on PR expression was confirmed in two other PR-expressing cell lines (T47D and BT474) (Supplementary Figure S1). Similarly to soluble FGFs, cancer-associated fibroblast (CAFs), known to be a rich source of various FGFs (including FGF7 [23]), had an impact on PR expression. MCF7 cells subjected to CAFsconditioned medium (CAF-CM) displayed a noticeable decrease of PR level (Supplementary Figure S2).

To verify engagement of FGF receptors in FGF7induced PR downregulation, cells were incubated with PD173074 (a well characterized, specific FGFR inhibitor $[35,36])$ and then stimulated with FGF7 (Figure 1B). Pretreatment with PD173074 nearly completely abolished FGF7-mediated downregulation of PR. Since it is well documented that FGF7 binds with the highest affinity to FGFR2 $[37,38]$, stable knock-down of FGFR2 gene was performed to confirm FGFR2 involvement in PR decrease in MCF7 and T47D cells. Results showed that 
FGFR2 silencing attenuated FGF7-triggered PR loss (Figure 1C-1D). Control experiment with another siRNA (targeting 5'-TTA GTT GAG GAT ACC ACA TTA-3' in FGFR2 [39]) excluded existence of a possible off-target effect (Supplementary Figure S3). These results indicate that FGF7/FGFR2 activation is involved in regulation of PR level in BCa cells.

\section{$P R$ is activated in FGF7-initiated signalling}

Progesterone receptor is activated upon binding of progesterone or its synthetic equivalents. Alternatively, PR activation can be induced independently of $\mathrm{Pg}$ through growth factors-related signalling [40]. To determine whether FGF7-triggered cascades affect PR, MCF7 cells were serum-starved and incubated for indicated periods of time with FGF7 or Pg (Figure 2A). As expected, FGF7 induced a gradual increase of phosphorylation of FGFR, Fibroblast Responsive Substrate 2 (FRS2) and AKT. Members of the MAPK family - ERK and p38 reached the peak of activation after 5 min of exposure to FGF7. We also observed that stimulation with FGF7 led to phosphorylation of PR at Ser190, Ser294 and Ser345 as well as rapid (after $5 \mathrm{~min}$ ) re-localization of cytoplasmic pool of PR to nucleus (Supplementary Figure S4).
Interestingly, FGF7-induced phosphorylation of PR and other analysed effectors preceded that triggered by $\mathrm{Pg}$ (Figure 2A). FGF7 seems to prime (as shown for other growth factors [41]) PR for Pg action which is reflected in enhanced transcription of CHN2 and RGS2 - PR-regulated genes [42] in cells simultaneously treated with FGF7 and Pg (Supplementary Figure S5). Knock-down of FGFR2 in MCF7 and T47D cell lines abolished FGF7-mediated activation of PR at Ser294 site (Figure 2B), confirming FGFR2 involvement in PR activation. Moreover, coimmunoprecipitation in relatively stringent conditions (1\% Triton X-100) suggested a possible direct interaction between FGFR2 and PR (Figure 2C), recently reported by Cerliani and co-workers [25].

\section{FGF7/FGFR2 promotes degradation of PR by 26S proteasome}

Previous studies indicated that $\mathrm{Pg}$ treatment leads to downregulation of PR via its degradation in the $26 \mathrm{~S}$ proteasome complex [28, 29, 43, 44]. Interestingly, analysis of PR downregulation kinetics in MCF7 cells revealed decrease of PR protein level faster upon FGF7 than Pg treatment (Figure 3A). A FGF7-triggered, gradually progressing drop in PR level was observed

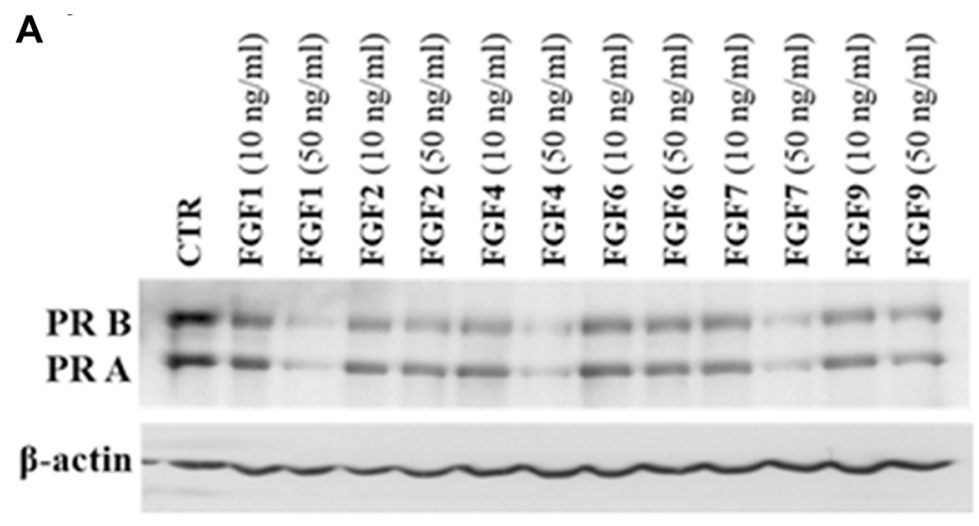

B

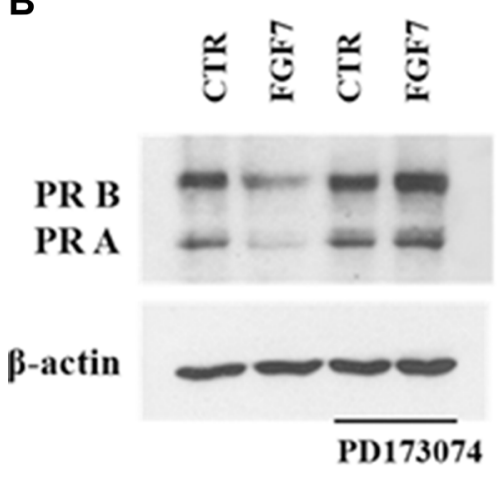

C

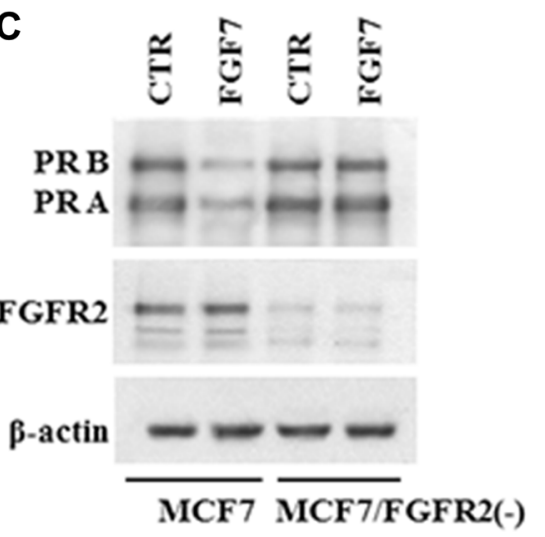

D

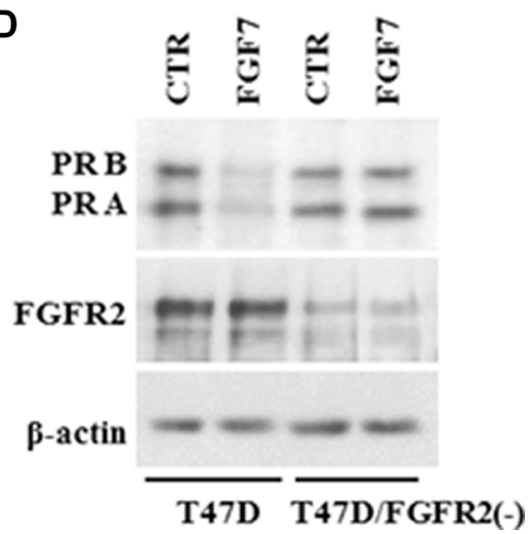

Figure 1: FGF/FGFR signalling downregulates PR. (A) MCF7 cells were serum starved and treated with a panel of FGFs $(10 \mathrm{ng} / \mathrm{ml}$ or $50 \mathrm{ng} / \mathrm{ml}$ ) for 48 hours. PR expression was evaluated by western blotting. (B) MCF7 cells were grown with/without FGFR inhibitor (PD173074, $100 \mathrm{nM}$ ), stimulated with FGF7 and analysed for PR expression. (C-D) Knockdown of FGFR2 in MCF7 and T47D cells abolishes FGF7-mediated effects. 
already after $2 \mathrm{~h}$ of exposure, while an impact of $\mathrm{Pg}$ on PR was first noticed after $12 \mathrm{~h}$ of stimulation. On the other hand, FGF7 did not significantly affect $P G R$ mRNA expression (Figure 3B). Function of PR is substantially determined by its post-translational modifications (i.e. phosphorylation, acetylation, ubiquitination, sumoylation) [45]. In particular, PR phosphorylation at Ser294 was proved to prime PR for translocation to the nucleus where it acts as a transcription factor. PR then shifts back to the cytoplasm and undergoes ubiquitination which is followed by its degradation in the $26 \mathrm{~S}$ proteasome complex [43]. Detected discrepancies in kinetics between Pg- and FGF7-induced PR downregulation might, therefore, be due to much faster activation of PR (Figure 2A) (including phosphorylation of Ser294) and subsequent activation of the proteasomal machinery in response to the latter. Kinetics of PR expression levels suggest that downregulation of PR in response to FGF7 does not involve regulation of $P G R$ transcription and results only from $P R$ protein degradation.

In order to confirm that the observed FGF7/FGFR2mediated downregulation of PR (Figure 1C-1D and 3A) was caused by receptor's degradation, MCF7 and T47D cells were incubated with MG132 (a well characterized, specific 26S proteasome inhibitor [46]) or leptomycin B (an inhibitor of nuclear export [47]) and then treated with FGF7 (Figure 3C, Supplementary Figure S6). We noted that an application of either inhibitor completely abolished FGF7-mediated downregulation of PR. In addition, western blot analyses of immunoprecipitated PR revealed that both Pg and FGF7 induced ubiquitination of PR (Figure 3D). Interestingly, the effect of FGF7 was brought about much faster than that induced by $\mathrm{Pg}$ (standardization experiment, data not shown), which is in agreement with observed ligand-specific kinetic of PR activation and subsequent degradation (Figure 2A and $3 \mathrm{~A}$ ). These results clearly indicate that FGF7/FGFR2 signalling triggers a cascade of events involving PR phosphorylation, ubiquitination and, eventually, proteasome-dependent receptor`s degradation.

It has been reported that PR levels can be affected by other growth factors [24, 48, 49]. Accordingly, cells were incubated for $24 \mathrm{~h}$ with IGF-1, heregulin (HRG) and EGF and their effect on PR expression at both protein and mRNA level (Figure 3E-3F), in relation to that induced by FGF7, was assessed by western blotting and qPCR, respectively. All analysed growth factors decreased PR at the protein level but the biggest drop was observed in response to FGF7. Importantly, the level of $P G R$ mRNA upon FGF7 and EGF (reported to induce PR proteasomal degradation [29]) treatment was reduced in only $20-30 \%$, whereas IGF and heregulin affected $P G R$ mRNA transcription and/or stability resulting in $50-80 \%$ reduction in mRNA level. These observations suggest that the effect of FGF7 on PR expression is due to protein degradation rather than downregulation of $P G R$ transcription.
A

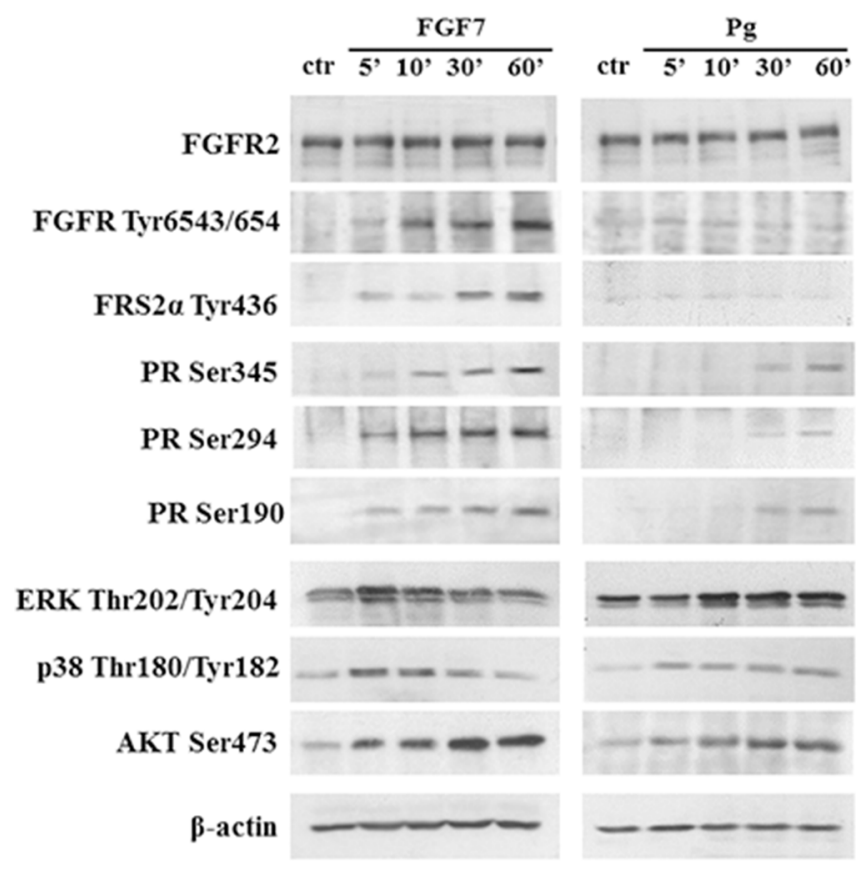

B
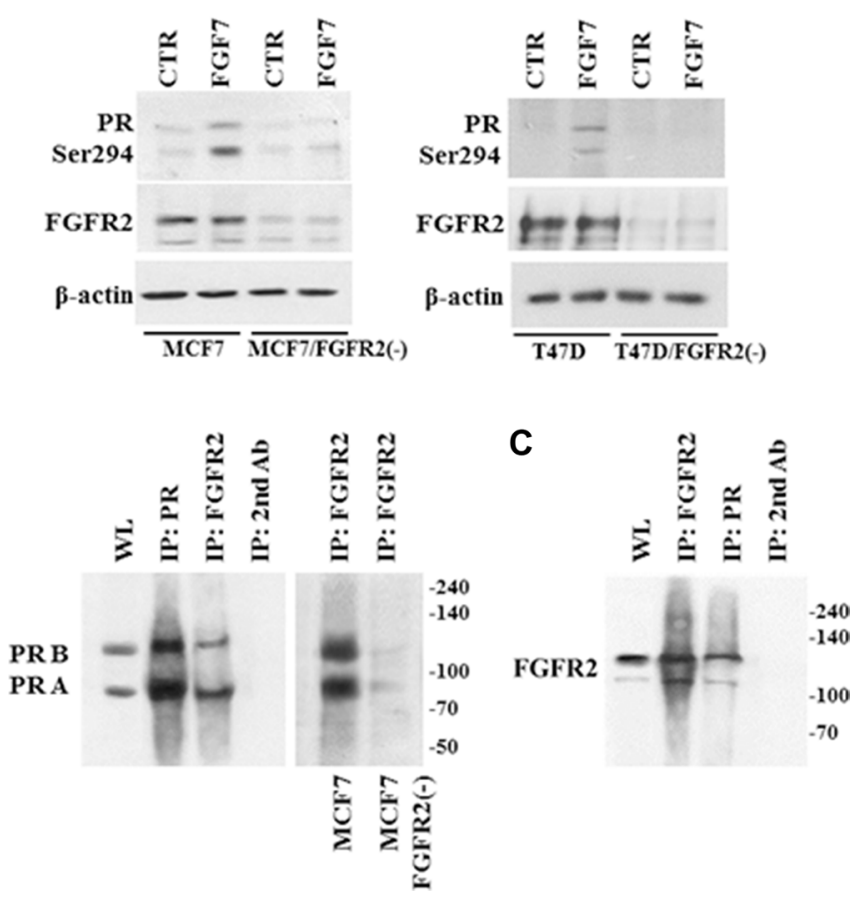

Figure 2: FGF7/FGFR2 activates PR. (A) PR is phosphorylated upon FGF7 stimulation. MCF7 cells were starved in serum-free media and incubated with FGF7 $(50 \mathrm{ng} / \mathrm{ml})$ or Pg $(100 \mathrm{nM})$ for indicated periods of time. (B) FGFR2 silencing in MCF7 and T47D cells abolishes FGF7-mediated activation of PR Ser294. (C) Interaction between FGFR2 and PR was verified by co-immunoprecipitation. Cell lysis was done in $1 \%$ Triton $\mathrm{X}-100, \mathrm{WL}$ - whole lysate. 


\section{RSK2 mediates FGF7/FGFR2-dependent PR degradation}

It has been previously shown that MAPK pathway is responsible for PR phosphorylation, an event crucial for receptor's function and stability [18]. In order to identify downstream mediators of MAPK pathway responsible for FGF7/FGFR2-induced degradation of PR we used inhibitors of the following kinases: MEK1/2 (U0126), p38 (SB202190) JNK (SP600125) and, based on our previous study [50], RSKs (FMK). MCF7 cells were pre-incubated with individual compound and then treated with FGF7 (Figure 4A). Application of inhibitors interfered to various degrees with FGF7-dependent effect on PR degradation. Strikingly, inhibition of RSKs completely abolished the observed PR downregulation. Analysis of PR Ser294 phosphorylation (Figure 4B) and receptor's ubiquitination (Figure 4C) revealed that activity of RSKs and, as previously shown ERK [43], is crucial for sequential events leading to PR proteasomal degradation. To verify an involvement of FGFR2-activated RSK2 in PR degradation we silenced RSK2 expression in MCF7 and T47D cell lines. As expected, knock-down of RSK2 affected FGF7-driven PR degradation (Figure 4D, Supplementary Figure S7) as well as PR Ser294 phosphorylation (Figure 4E). On the other hand, overexpression of constitutively active RSK2 [51, 52] did not affect steady-state level of PR but increased FGF7-mediated downregulation of PR. The latter was abolished by inhibitor of either RSK or FGFR (Supplementary Figure S8). These suggest that RSK2 targets PR specifically in the FGFR2 signalling. Coimmunoprecipitation analysis revealed that RSK2 and PR are likely to get into direct, transient interaction upon FGF7/FGFR2 signalling (Figure 4F). Taken together, our findings clearly identify RSK2 as a member of the PR regulatory system.

\section{FGF7/FGFR2 regulates PR-dependent cell activities}

Previous studies indicated that growth factors exerted a faster and stronger effect on PR-mediated proliferation and migration of BCa cells than that caused by $\mathrm{Pg} /$ progestin alone $[31,41]$. To investigate functional consequences of FGF7/FGFR2 involvement in PR-related cell behaviour, we evaluated anchorage-independent growth of MCF7 cells upon stimulation with Pg and/ or FGF7 (Figure 5A). We found that both Pg and FGF7
A

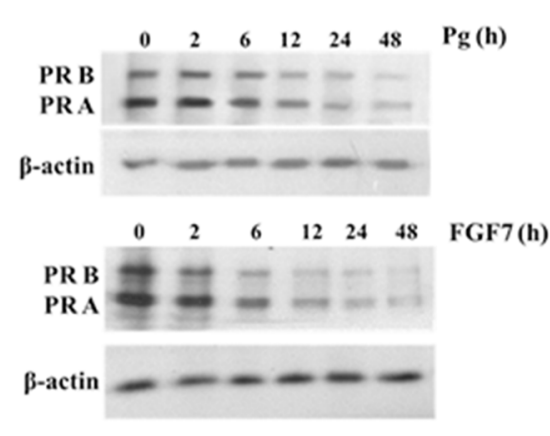

D

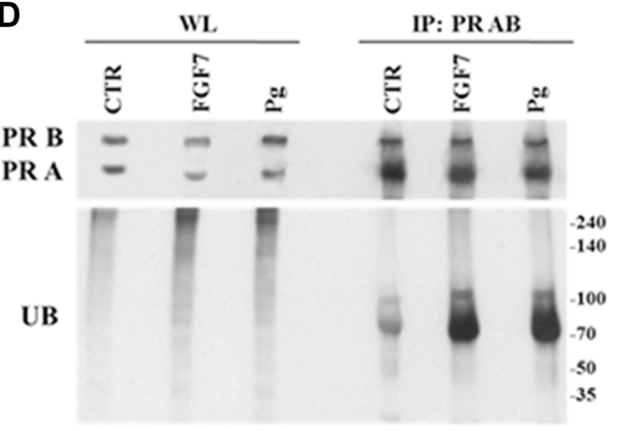

B

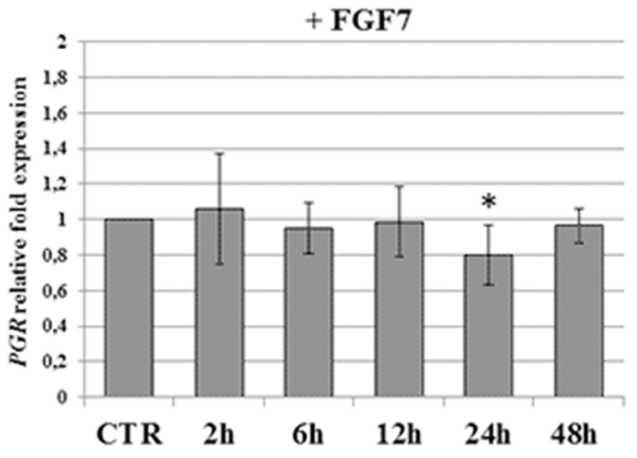

C

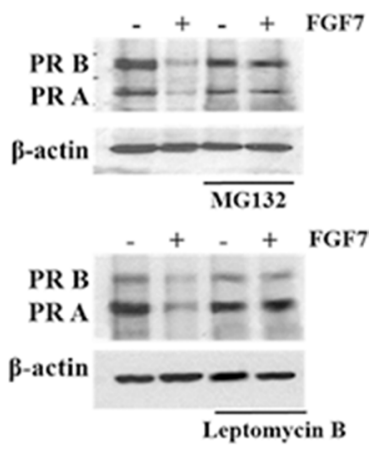

E

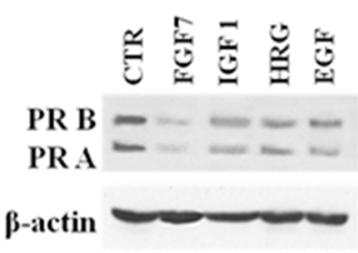

$\mathbf{F}$

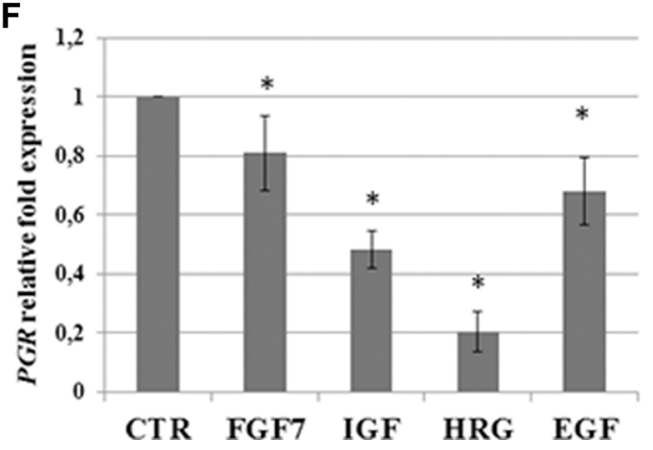

Figure 3: FGF7/FGFR2 promotes PR degradation via proteasome complex. (A) Various kinetics of PR downregulation upon Pg $(100 \mathrm{nM})$ or FGF7 $(50 \mathrm{ng} / \mathrm{ml})$ exposure. Time points as indicated. (B) qPCR analysis of $P G R$ mRNA level upon treatment with FGF7. (C) FGF7 induces proteasomal degradation of PR in cytosol. MCF7 cells were pre-treated with leptomycin B (0.5 nM) or MG132 (2 $\mu$ M) and incubated with FGF7 (50 ng/ml) for $24 \mathrm{~h}$. (D) FGF7 triggers PR ubiquitination. MCF7 cell were serum starved and incubated with FGF7 $(50 \mathrm{ng} / \mathrm{ml})$ or Pg $(100 \mathrm{nM})$ for 3 or $4 \mathrm{~h}$, respectively. Cell lysis and immunoprecipitation of PR was done in $1 \%$ Triton-X. Ubiquitination level was evaluated by western blot analyses. Protein amount in both lysate (WL) and immunoprecipitated fraction was normalized. $(\mathbf{E}, \mathbf{F})$ Effect of various growth factors on PR downregulation and $P G R$ mRNA level (assessed by qPCR), $n=3,{ }^{*} p$ value $\leq 0.05$. 
promoted cell growth in soft agarose. Importantly, their simultaneous application revealed an additive effect on cell growth. Evaluation of pro-migratory action of FGF7/PR interdependence showed a similar tendency - a cumulative, motility promoting effect of combined FGF7 and $\mathrm{Pg}(\sim 2.13-$ fold vs. $\sim 1.36$-fold for $\mathrm{Pg}$ and 1.11 for FGF7 treatment) (Figure 5B). Enhancement of Pg action by FGF7 was additionally confirmed at the molecular level in cells treated with $\mathrm{Pg}$, FGF7 or Pg/FGF7. Both $\mathrm{Pg}$ and FGF7 induced phosphorylation of key mediators of cell migration i.e. FAK, Src and paxillin (Figure 5C) but the strongest effect (particularly on Src and FAK, as shown by densitometry - ImageJ software) was observed in cells treated with their combination. These data are in agreement with previously reported sensitization of PR to $\mathrm{Pg}$ by growth factors $[18,29,41]$.

\section{Poor prognosis of RSK-P-positive/PR-negative patients}

We have recently demonstrated that both FGFR2 and RSK2 were expressed in primary breast cancer samples and lack of combined immunoreactivity for FGFR2 and activated RSK (RSK-P) was predictive of a better patients' disease-free survival [30]. Here, we further evaluated clinical significance of the FGFR2/RSK-P pathway and, in the same group of patients $(N=152$, Supplementary Table S1), assessed expression of FGFR2, RSK2 and RSK-P in relation to clinicopathological features, and in particular, the PR status. Expression of PR was seen predominantly in the nucleus, whereas the pattern of immunoreactivity for remaining proteins was highly heterogeneous with regards to both cellular localization and level of expression. Examples of levels of high and low expression (classified as positive and negative, respectively) are presented on Figure 6. FGFR2 expression showed, as previously reported [25], a positive, statistically significant association with PR (Table $1, p=0.000006$ ). There was also a correlation between expression of PR and RSK2 $(p=0.023)$. Importantly, RSK-P showed inverse correlation with PR status $(p=0.016)$, which gives support to the functional significance of identified in vitro RSK2-dependent downregulation of $\mathrm{PR}$. Analysis of relationships between the RSK-P(+)/PR(-) phenotype and clinicopathological characteristics revealed statistically significant associations with grade and inverse with ER (Table 2). Patients with RSK-P(+)/

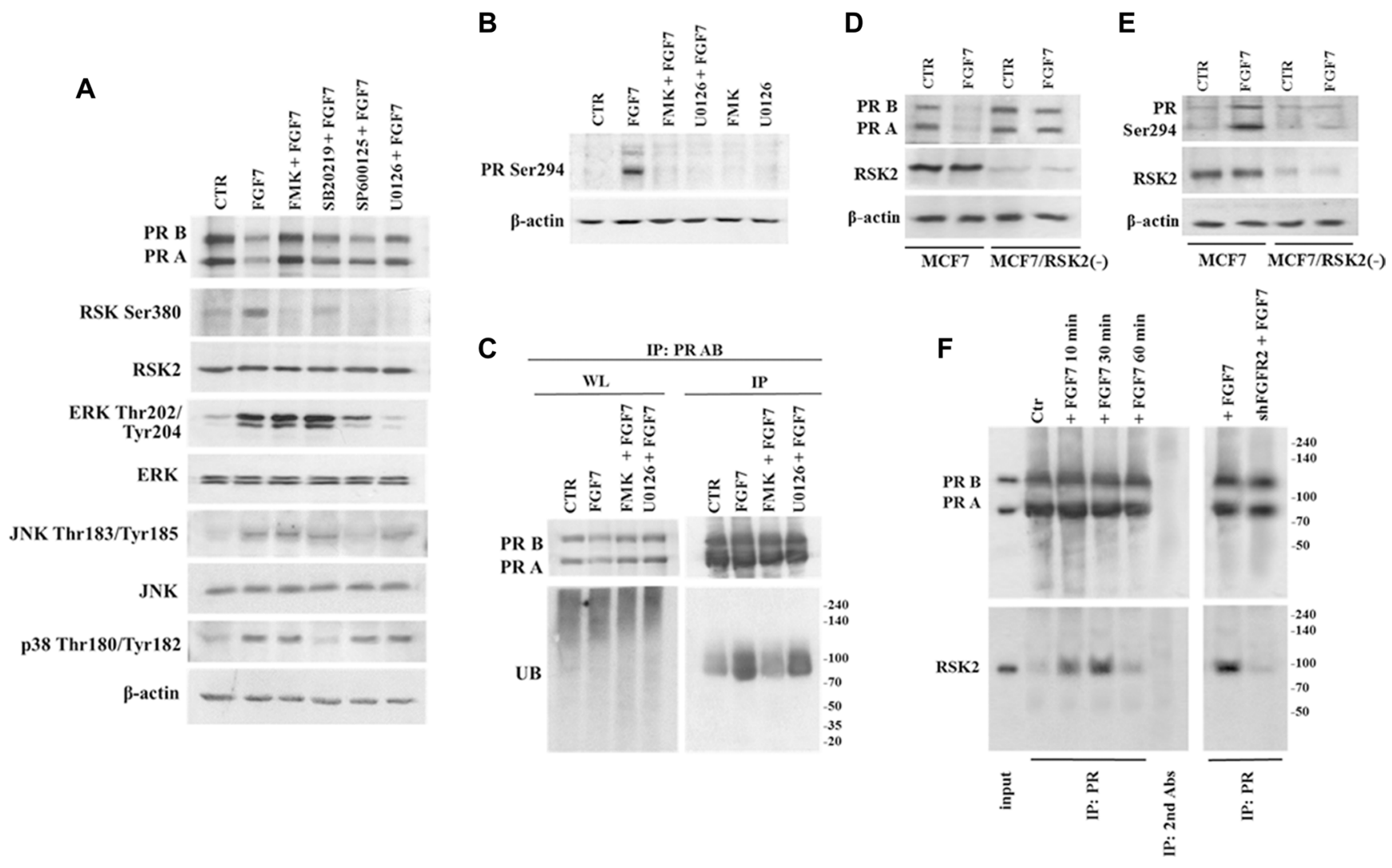

Figure 4: RSK2 mediates FGF7/FGFR2-dependent degradation of PR. (A) Involvement of various members of MAPK signalling pathway in FGF7/FGFR2-dependent PR degradation. Cells were pre-treated with following inhibitors FMK (10 $\mu$ M), U0126 $(10 \mu \mathrm{M})$, SB202190 $(10 \mu \mathrm{M})$ or SP600125 $(10 \mu \mathrm{M})$ and stimulated with FGF7 $(50 \mathrm{ng} / \mathrm{ml})$ for $24 \mathrm{~h}$. (B) RSKs activity is responsible for PR Ser294 phosphorylation (upon $60 \mathrm{~min}$ of exposure to FGF7) and (C) PR ubiquitination (upon 3 h of exposure to FGF7). Protein amount in both lysate (WL) and immunoprecipitated fraction was normalized. (D) Knock-down of RSK2 abrogates PR degradation and (E) phosphorylation. (F) FGF7/FGR2 signalling results in formation of transient PR/RSK2 complex. 
PR(-) tumours had 3.629-fold higher risk of recurrence (Table 3, $p=0.002$ ), when compared with the rest of the cohort (Figure 7, $p=0.001$ ). Moreover, RSK-P $(+) /$ $\mathrm{PR}(-)$ phenotype was shown an independent marker of recurrence (Table 3, $p=0.006$ ).

\section{DISCUSSION}

In response to $\mathrm{Pg}$ (or synthetic ligands) binding, PR dimerizes and translocates to the nucleus. It acts there as a transcription factor which is followed by its re-
A
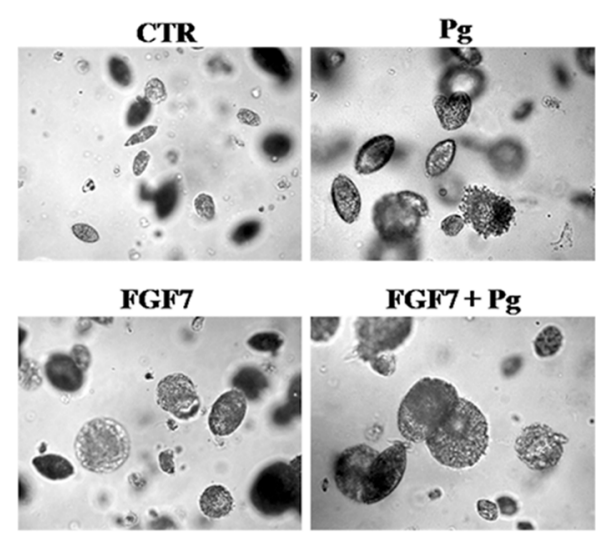

B
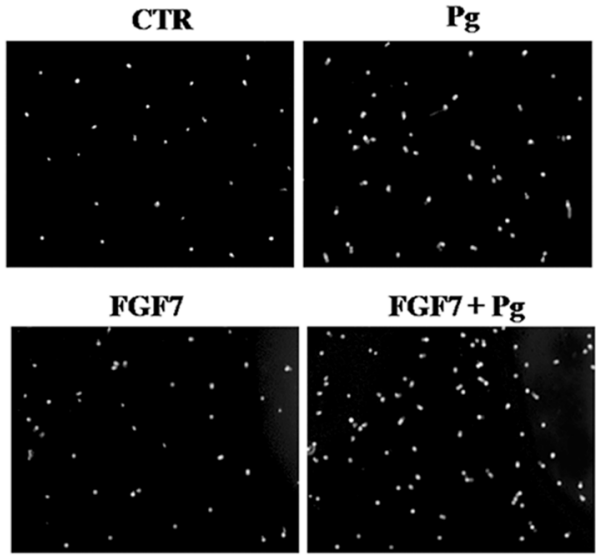
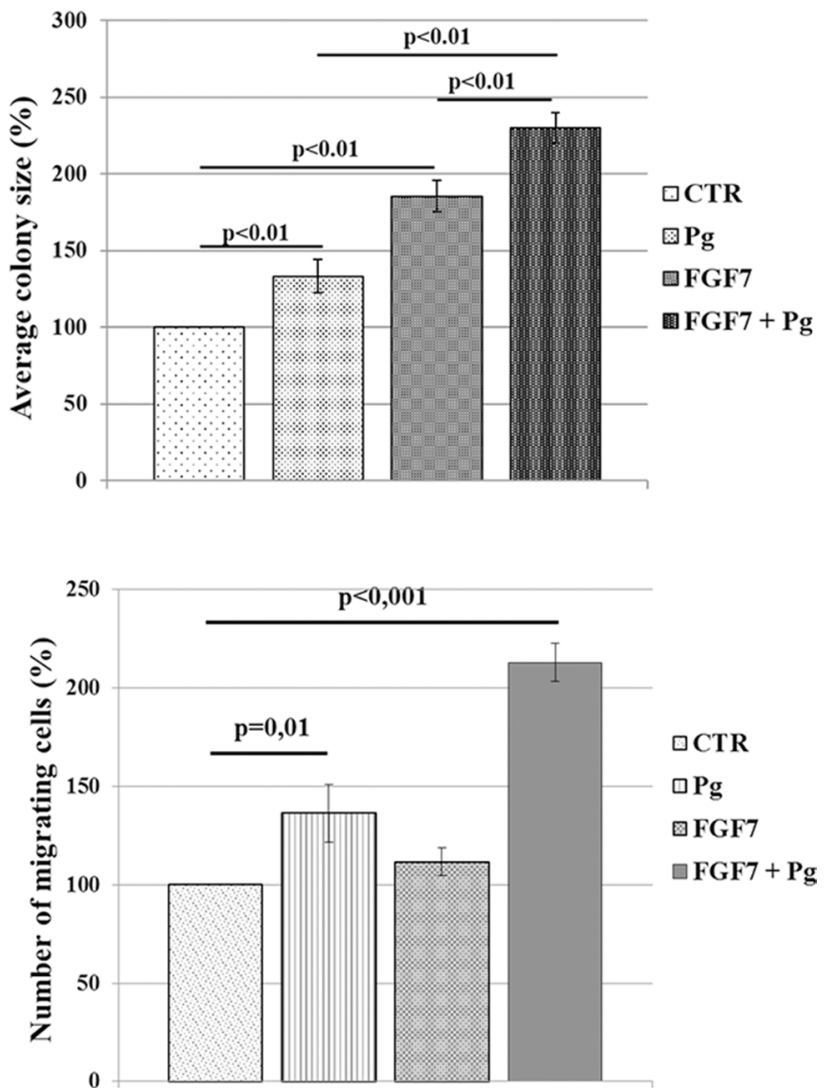

C

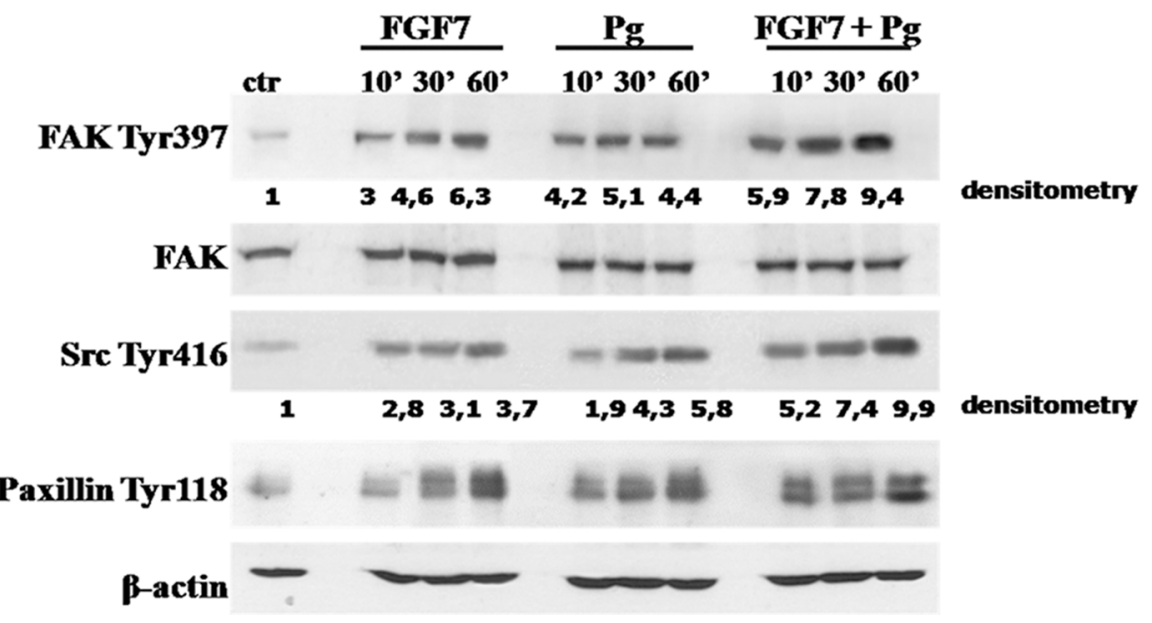

Figure 5: FGF7/FGFR2 regulates PR-mediated cell behaviour. (A) Synergistic effect of FGF7 and Pg on MCF7 cells growth in soft agarose. MCF7 colonies were cultured in soft agarose in media supplemented with Pg (100 nM) and/or FGF7 (10 ng/ml) for 30 days. The values presented are means $\pm \mathrm{SD}(n=3)$. (B) FGF7 enhances Pg pro-migratory effect. Cells migrated towards medium supplemented with Pg $(100 \mathrm{nM})$ and/or FGF7 $(50 \mathrm{ng} / \mathrm{ml})$. The values presented are means $\pm \mathrm{SD}(n=3), p$ value indicated on graphs. (C) Activation of FAK, Src and paxillin upon Pg and/or FGF7 treatment. Experiment was highly reproducible. The experiment was done in duplicate. 
Table 1: Correlation of PR with FGFR2, RSK2 and RSK-P in BCa

\begin{tabular}{lccc}
\hline \multirow{2}{*}{ correlation } & tau & $\boldsymbol{p}$ & $\boldsymbol{N}$ \\
\cline { 2 - 4 } & Kendall & $\mathbf{0 . 0 0 0 0 0 6}$ & 133 \\
\hline PR \& FGFR2 & 0.2649 & $\mathbf{0 . 0 2 3}$ & 124 \\
PR \& RSK2 & 0.1377 & $\mathbf{0 . 0 1 6}$ & 125 \\
PR \& RSK-P & -0.1456 & .
\end{tabular}

Samples analysed by IHC for proteins expression. Numerical values of correlations coefficients (Kendall's tau), $p$ values and number of patients are presented in the corresponding boxes.

Table 2: Association between RSK-P(+)/PR(-) phenotype and clinicopathological features analysed by IHC in BCa samples

\begin{tabular}{lcc}
\hline \multirow{2}{*}{ Feature } & P value \\
\cline { 2 - 3 } & RSK-P(+)/PR(-) \\
\hline Tumor size & 0.180 \\
Nodal status & 0.549 \\
Grade & $\mathbf{0 . 0 0 0 0 5}$ \\
HER2 & 0.075 \\
ER(-) & $\mathbf{0 . 0 0 0 1 2}$ \\
\hline
\end{tabular}

Statistically significant $p$ values are given in bold.

translocation to the cytoplasm and subsequent degradation. Recent data have shown that the PR can also be activated by an alternative mechanism involving growth factor receptors (e.g. EGFR, IGFR, FGFR2)-triggered signalling $[24,25,53]$.

It has been well documented that cancer-associated fibroblasts secrete a number of growth factors, including FGFs [23], implicated in cancer progression and lack of responsiveness to treatment [49]. In particular, FGFR2 and its ligands were shown to contribute to $\mathrm{BCa}$ development $[32,37,54]$, but their possible involvement in the regulation of steroid hormone receptors function still remains poorly understood. Giulianelli and co-workers reported that $\mathrm{PR}$ can be activated in response to $\mathrm{CAF}$ secreted FGF2, which may play part in the development of $\mathrm{BCa}$ hormone-independence. In a more recent study, they revealed a mechanistic association between FGFR2 and steroid hormone receptor, demonstrating a nuclear interaction between FGFR2 and STAT5, as PR coactivators at the DNA PR-responsive elements [25]. Results of our study showed that stimulation of $\operatorname{PR}(+)$ breast cancer cell lines with various FGFs decreased level of PR with the highest impact being observed for FGF1, FGF4, FGF7. As expected, downregulation of PR was also noticed upon treatment with CAF-conditioned medium. There are a number of studies of the role of FGF7 in biology of the mammary gland [32-34]. In light of these findings implicating FGF7 in both physiology and carcinogenesis of the mammary gland, FGF7 has been chosen for our analyses of the interdependence between FGFs/FGFR2 and PR. Binding of FGF7 to the FGFR2, as demonstrated for other FGFs affecting PR level [37], was confirmed in MCF7 cells, where stable knock-down of FGFR2 nearly completely abolished FGF7-mediated downregulation of PR. It is likely, therefore, that the observed effect of CAFs on PR expression was brought about by the FGF7/FGFR2dependent mechanism.

It has been reported that PR can be activated by growth factors (i.e. EGF, HRG), independently of $\mathrm{Pg}$ and, interestingly, much faster than by its cognate ligand $[26,55]$. We confirmed these observations and found that in MCF7 cells, FGF7-mediated PR downregulation was indeed more swiftly initiated than the process triggered by Pg. We also verified cross-talk between FGFR and PR signalling and observed phosphorylation of $\mathrm{PR}$ in response to treatment with both Pg and FGF7. This is in agreement with previously reported effects of growth factors on PR activation $[18,25,55]$. Surprisingly, we did not observe phosphorylation of FGFR or its direct downstream effector - FRS2 $\alpha$ in response to Pg (Figure 2A) demonstrated recently by Cerliani and co-workers [25]. This discrepancy could be due to a different cell line model and/or applied conditions of stimulation (Pg instead of synthetic progestin R5020). However, similarly to Cerliani et al., we confirm a possible direct interaction between FGFR2 and PR.

Phosphorylation of PR at Ser294 is considered to prime PR for translocation to the nucleus, increase PR transcriptional activity and trigger PR ubiquitination with subsequent degradation in the cytoplasm [18]. Interestingly, we observed FGF7/FGFR2-dependent 
activation of PR at Ser294. This suggests that downregulation of PR triggered by FGF7 is associated with receptor degradation rather than regulation of $P G R$ transcription. This has been verified by application of MG132 - 26S proteasome inhibitor and Leptomycin B nuclear export inhibitor, which both nearly completely abrogated FGF7-mediated PR downregulation. Analyses of an impact of FGF7 vs. other growth factors (e.g. IGF1, HRG or EGF) on PR protein and $P G R$ mRNA level showed that FGF7 affected mainly the former with the weakest effect, of all tested GFs, on PGR mRNA expression. We also found that stimulation with FGF7 enhanced the process of PR ubiquitination to the same extent as did the Pg treatment. Interestingly, we observed that ubiquitination of PR proceeded faster in response to FGF7 than $\mathrm{Pg}$, which may be a result of presented differences in kinetics of PR activation triggered by these two factors.
Molecular mediators of the FGF7/FGFR2-initiated PR degradation have not been unequivocally recognised yet. However, MAPK pathway was strongly suggested to regulate PR activity, including Ser294 phosphorylation known to be indispensable for PR degradation [43]. Our previous studies identified RSK2 as a downstream target of FGF2/FGFR2 signalling pathway [50]. Importantly, RSK2 was demonstrated to closely relate to MSK1/2, proved to interact with and activate PR [56]. Application of various inhibitors of individual members of the MAPK family indicated, as previously reported [57], that p38 and ERK activity was involved in PR degradation. Importantly, in our analyses, the strongest inhibitory effect, nearly completely abolishing FGF7-mediated PR degradation, was noted in cells pre-incubated with FMK (RSKs inhibitor). Inhibition of RSKs elevated PR level, even in control (non-treated) cells, which may suggest a primary role of RSKs in regulation of PR

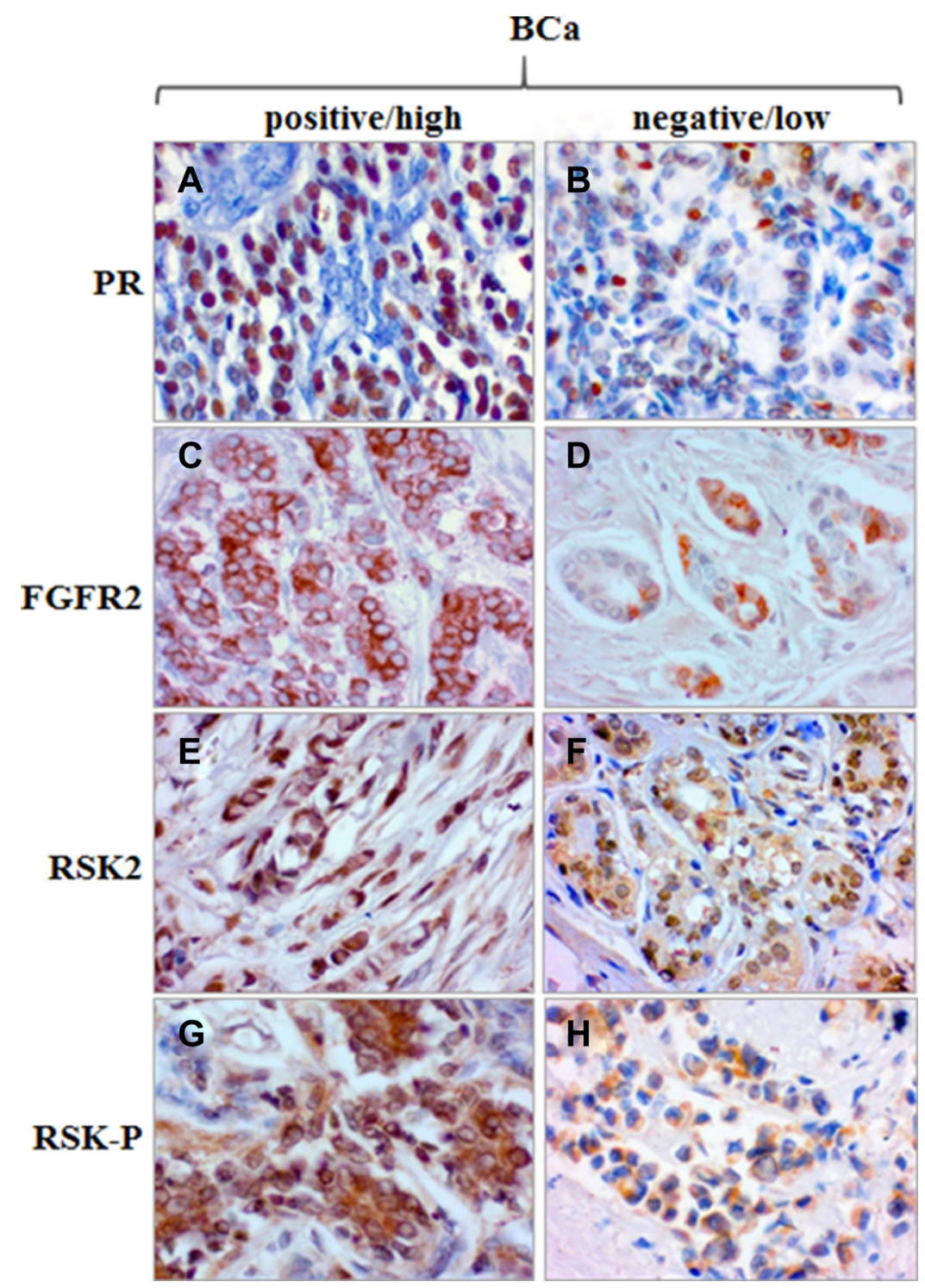

Figure 6: Expression of PR, FGFR2, RSK2 and RSK-P in BCa tissue samples. Examples of high/positive and low/negative immunoreactivity for PR (A/B), FGFR2 (C/D), RSK2 (E/F) and RSK-P (G/H). 
Table 3: Univariate and multivariate analysis of prognostic factors

\begin{tabular}{|c|c|c|c|c|c|c|}
\hline \multirow[b]{2}{*}{ Variable } & \multicolumn{3}{|c|}{$\begin{array}{l}\text { UNIVARIATE ANALYSIS } \\
\text { DFS }\end{array}$} & \multicolumn{3}{|c|}{$\begin{array}{c}\text { MULTIVARIATE ANALYSIS } \\
\text { DFS }\end{array}$} \\
\hline & $N$ & $\begin{array}{l}\text { Hazard ratio } \\
(95 \% \mathrm{CI})\end{array}$ & $p$ & $N$ & $\begin{array}{l}\text { Hazard ratio } \\
(95 \% \mathrm{CI})\end{array}$ & $p$ \\
\hline $\begin{array}{c}\text { Tumor size } \\
\text { (T3-4 vs. T1-2) }\end{array}$ & 151 & $\begin{array}{c}4.745 \\
(2.220-10.142)\end{array}$ & 0.00006 & 124 & $\begin{array}{c}5.830 \\
(2.240-15.170)\end{array}$ & 0.0003 \\
\hline $\begin{array}{c}\text { Nodal status } \\
\text { (positive vs. negative) }\end{array}$ & 150 & $\begin{array}{c}2.373 \\
(1.091-5.162)\end{array}$ & 0.029 & & & NS \\
\hline $\begin{array}{c}\text { ER } \\
\text { (positive vs. negative) }\end{array}$ & 149 & $\begin{array}{c}0.523 \\
(0.257-1.062)\end{array}$ & 0.073 & & & NS \\
\hline $\begin{array}{c}\text { PR } \\
\text { (positive vs. negative) }\end{array}$ & 149 & $\begin{array}{c}0.367 \\
(0.180-0.750)\end{array}$ & 0.006 & & & - \\
\hline $\begin{array}{c}\text { Grade } \\
\text { (G3 vs. G1-2) } \\
\end{array}$ & 132 & $\begin{array}{c}1.469 \\
(0.652-3.308) \\
\end{array}$ & 0.353 & & & NS \\
\hline $\begin{array}{c}\text { HER2 status } \\
\text { (positive vs. negative) }\end{array}$ & 128 & $\begin{array}{c}1.348 \\
(0.503-3.612)\end{array}$ & 0.553 & & & NS \\
\hline $\begin{array}{c}\text { RSK2 } \\
\text { (positive vs. negative) }\end{array}$ & 124 & $\begin{array}{c}0.699 \\
(0.293-1.666) \\
\end{array}$ & 0.419 & & & NS \\
\hline $\begin{array}{c}\text { RSK-P } \\
\text { (positive vs. negative) }\end{array}$ & 127 & $\begin{array}{c}2.134 \\
(0.790-5.765)\end{array}$ & 0.135 & & & - \\
\hline $\begin{array}{l}\text { RSK-P(+)/PR(-) } \\
\text { vs. rest }\end{array}$ & 125 & $\begin{array}{c}3.629 \\
(1.599-8.237)\end{array}$ & 0.002 & 124 & $\begin{array}{c}3.193 \\
(1.393-7.321)\end{array}$ & 0.006 \\
\hline
\end{tabular}

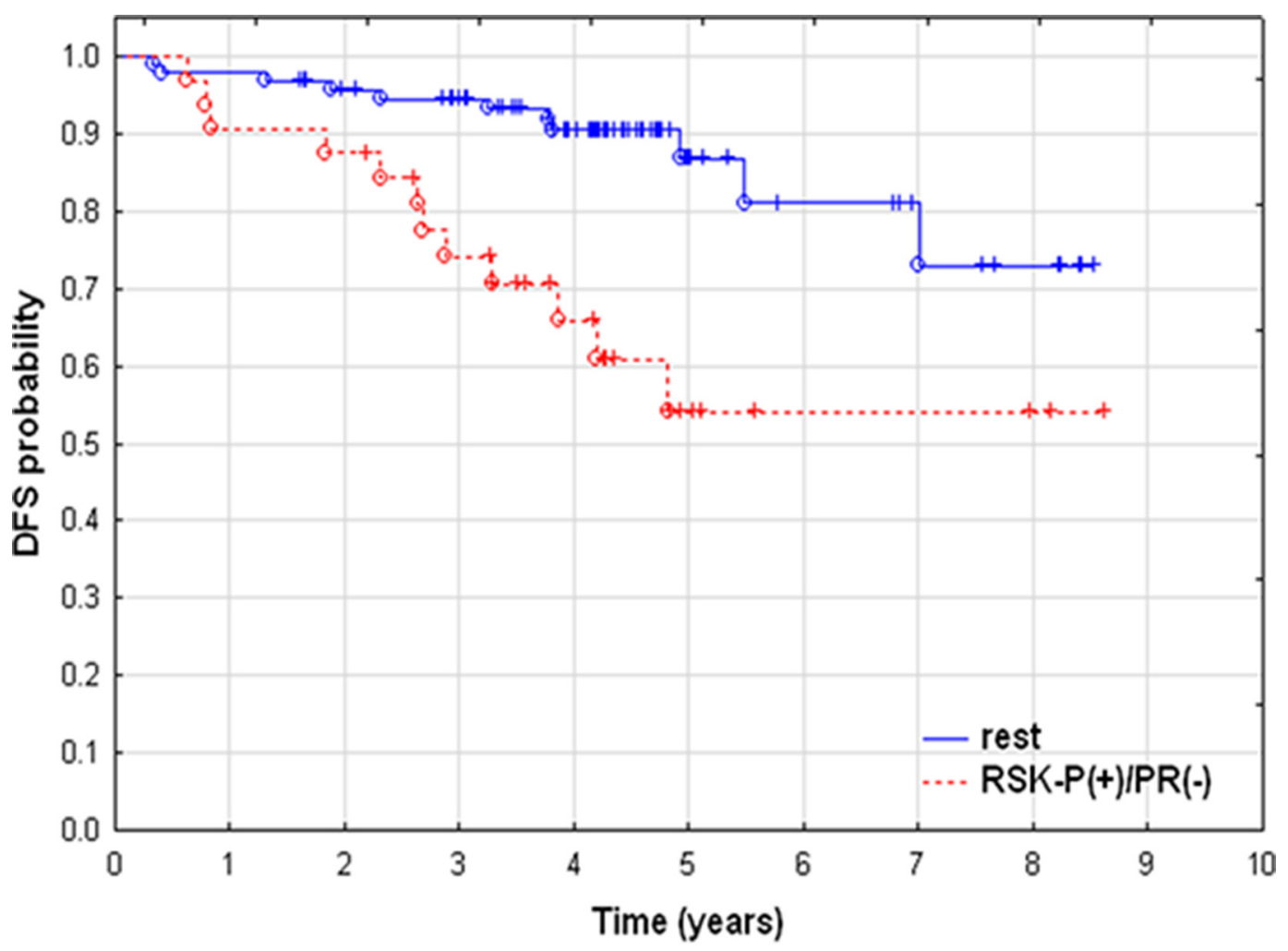

Figure 7: Poor prognosis of RSK-P-positive/PR-negative patients. Kaplan-Meier curves of disease-free survival. Patients with RSK-P(+)/PR $(-)(N=32)$ vs. rest of the cohort $(N=93)$. 
function. In addition, RSKs seemed to be involved in PR phosphorylation at Ser294 and receptor's ubiquitination in response to FGF7. We also identified RSK2, as a member of the RSK family important for regulation of PR function. Co-immunoprecipitation suggested a possible direct interaction between RSK2 and PR upon FGF7/FGFR2 signalling. As, RSK2 was previously shown to activate and interact with estrogen receptor [58], it may indicate RSK2 as an essential mediator of a likely universal mechanism of regulation of a steroid hormone receptors activity.

Evaluation of cellular effects of the cross-talk between FGF7/FGFR2 and PR revealed that FGF7 or $\mathrm{Pg}$, tested separately, stimulated anchorage-independent growth and migration of breast cancer cells. Combination of both agents disclosed a clear synergism between them, reflected by enhancement of cell growth and motility. Analysis of activation of proteins directly involved in regulation of cell migration (i.e. FAK, Src, paxillin) upon cells' treatment with FGF7 and/or Pg suggested they may have exerted a cumulative biological effect. As previously demonstrated [18], these data together with analyses of expression of PR-dependent genes upon FGF and/or Pg stimulation (Supplementary Figure S5) strongly imply that PR, primed by growth factors (including FGF7), may respond more efficiently to its steroid cognate ligand.

Clinical significance of FGFR2-RSK2 signalling pathway was analysed in breast cancer samples in relation to the PR status. Results demonstrated that positivity for RSK-P identified a subgroup of patients with PR-negative $\mathrm{BCa}$ with increased risk of recurrence. Furthermore, $\mathrm{RSK}-\mathrm{P}(+) / \mathrm{PR}(-)$ phenotype was found an independent marker of poor disease-free survival. In addition, PR expression inversely correlated with RSK-P, which is in agreement with our in vitro observations and gives weight to biological meaning of investigated molecular mechanisms. Taken together, our study demonstrated for the first time that the FGF7/FGFR2-triggered signalling pathway, involving RSK2 activity and targeting PR, may be a new mechanism of breast cancer progression in response to stromal (e.g. cancer-associated fibroblasts) stimuli toward steroid hormone negative $\mathrm{BCa}$.

\section{MATERIALS AND METHODS}

\section{Cell lines, antibodies, reagents}

MCF7, T47D and BT474 cell lines were obtained from ATCC. Cell lines were passaged for a maximum of 3-4 months post resuscitation and regularly tested for mycoplasma contamination. MCF7 and T47D cells were routinely maintained in DMEM, BT474 in RPMI supplemented with insulin $(5 \mu \mathrm{g} / \mathrm{ml})$. All media contained $10 \%$ FBS and penicillin/streptomycin $(100 \mathrm{U} / \mathrm{ml} /$ $100 \mu \mathrm{g} / \mathrm{ml}$ ). For analyses of PR function, phenol red-free media and dextran charcoal-treated FBS were used. All media and supplements were purchased from Sigma-Aldrich or HyClone. The following antibodies were obtained from Santa Cruz Biotechnology: anti-FAK (sc-558), anti-FGFR2 (sc-122), anti-PR (sc-7208), anti-Ub (sc-8017). Antibody against $\beta$-actin (A5316) was obtained from Sigma-Aldrich. All the remaining antibodies were from Cell Signaling Technology: anti-AKT (\#9272), anti-AKT-Ser473 (\#4048), anti-ERK1/2-Thr202/Tyr204 (\#9101), anti-FAK-Tyr397 (\#3283), anti-FGFR-Tyr653/654 (\#3471), anti-FRS2 $\alpha$ Tyr436 (\#3861), JNK-Thr183/Tyr185 (\#9251), anti-p38Thr180/Tyr182 (\#9211), anti-paxillin-Tyr118 (\#2541), anti-PR-Ser190 (\#3171), anti-PR-Ser345 (\#12783), antiRSK2 (\#5528), anti-RSK-Ser380 (\#9335), anti-RSKThr359/Ser363 (\#9344), anti-Src-Tyr416 (\#6943). AntiPR-Ser294 antibodies were kindly provided by Dr Carol Lange (University of Minnesota). All growth factors were purchased from PeproTech. Heparin sodium salt and inhibitors: PD173074, U0126, SB20219, SP600125, FMK, MG132, Leptomycin B were from Sigma-Aldrich.

\section{Western blotting and immunoprecipitation}

Cells were harvested at $60-70 \%$ of confluency in cold PBS and lysed with Laemmli buffer ( $2 \mathrm{x}$ concentrated) supplement by $2 \mathrm{mM}$ PMSF, $10 \mu \mathrm{g} / \mathrm{ml}$ aprotinin, $10 \mu \mathrm{g} / \mathrm{ml}$ leupeptin, $5 \mathrm{mM}$ EGTA, $1 \mathrm{mM}$ EDTA, $2 \mathrm{mM} \mathrm{Na}_{4} \mathrm{P}_{2} \mathrm{O}_{7}$, $5 \mathrm{mM} \mathrm{NaF}$ and $5 \mathrm{mM} \mathrm{Na} \mathrm{VO}_{4}$. Samples containing equal amounts of protein per lane were loaded, resolved in SDS-PAGE and then transferred onto nitrocellulose membrane. The membranes were incubated for $1 \mathrm{~h}$ in $5 \%$ skimmed milk and probed overnight with specific primary antibodies at $4{ }^{\circ} \mathrm{C}$. Secondary antibodies conjugated with HRP (Sigma-Aldrich) and Western Lightning Plus-ECL (PerkinElmer) were used to visualize specific proteins. For immunoprecipitation experiments, cells were lysed in lysis buffer containing 1\% Triton X-100. Supernatant was incubated with $2 \mu \mathrm{g}$ of appropriate antibody overnight at $4{ }^{\circ} \mathrm{C}$. The samples were incubated with protein $\mathrm{A}$ or protein G beads (Santa Cruz Biotechnology, sc-2001, sc-2002) according to the manufacturer's instructions. Immunocomplexes were eluted from beads with Laemmli buffer and analysed by western blotting.

\section{qPCR}

RNA was isolated with TriPURE reagent (Roche) according to the manufacturer's protocol. Reverse transcription with random hexamer primers was done with Transcriptor cDNA First Strand Synthesis Kit (Roche). PGR gene and PR-dependent genes expression analyses were carried out with TaqMan (Applied Biosystem) probes -PGR (Hs01556702_m1), CHN2 (Hs00906968_m1), RGS2 (Hs01009070_g1) with ACTB (Hs99999903_m1) and GAPDH (Hs99999005_m1) used as reference genes. Twenty microliter reactions were conducted applying TaqMan Universal PCR Master Mix (Applied Biosystem) on 96-well plates in CFX96 cycler (Bio-Rad, Hercules). 
Reactions were done in duplicates. Each plate contained an inter-run calibrator - a set of non-template controls and controls for cDNA contamination. Gene expression was calculated using a modified $\Delta \Delta \mathrm{C}$ approach, as previously described [59].

\section{Soft agarose assay for anchorage-independent growth}

The $5 \times 10^{4}$ cells per well of 6 -well plate were re-suspended in $3 \mathrm{ml}$ of $0.4 \%$ low gelling temperature agarose (Sigma) prepared in DMEM containing 10\% FBS and overlaid on $3 \mathrm{ml}$ solidified $0.5 \%$ agarose made up in the same medium. The top layer was covered with $3 \mathrm{ml}$ of regular medium supplemented, when appropriate, with FGF7 $(10 \mathrm{ng} / \mathrm{ml})$ and/or Pg $(100 \mathrm{nM})$. The medium was refreshed every 3 days. After 21 days of culture, colonies were counted and measured with ZEISS PrimoVert microscope and ImageJ software.

\section{Migration assay}

Cell migration was assessed as previously described [60]. Briefly, MCF7 cells were serum-starved overnight. Next day cells were detached with enzymefree cell dissociation buffer (Millipore) and $1.5 \times 10^{5}$ cells resuspended in serum-free DMEM. The polycarbonate membranes ( $8 \mu \mathrm{m}$ pores, BD Bioscience) of inserts were coated with high concentration Matrigel (BD Bioscience) diluted in serum-free DMEM (1:1000). Cells were placed in the inner compartment of Boyden chamber inserts and allowed to migrate for $24 \mathrm{~h}$ toward DMEM (10\% FBS) $\pm 50 \mathrm{ng} / \mathrm{ml} \mathrm{FGF7}$ and/or $100 \mathrm{nM} \mathrm{Pg}$. Non-migrated cells were removed by cotton swab. Membranes were mounted onto glass slides, cells stained with DAPI and counted in 20 random fields (100x) under AxioVert 200 fluorescent microscope.

\section{FGFR2 knock-down, RSK2 knock-down, overexpression of RSK2}

MCF7/FGFR2(-) and MCF7/RSK2(-) cell lines were generated with lentiviral system based on pLKO.1-TRC vector (Addgene, \#10878) with cloned shRNA designed on the basis of the following siRNA sequences: FGFR2 5'-GAG AUU UGG UAU UUG GUU GGU GGC -3' [61], RSK2 5'-UUG CUG UCC AUU CUC AGC GCU-3' [62]. Overexpression of RSK2 was generated with pWZL Neo Myr Flag RPSK6A3 plasmid (Addgene, \#20627). Transfection was done with TurboFect Transfection Reagent (Thermo Scientific) according to the manufacturer's protocol. Stable cell line expressing constitutively active RSK2 were established by neomycin (Sigma Aldrich) selection.

\section{Stimulation with growth factors, inhibitors effect, signalling analyses}

For analysis of growth factors-triggered signalling, cells were serum starved overnight before growth factors were added. Cells were stimulated with various FGFs at 10 or $50 \mathrm{ng} / \mathrm{ml}$ and/or Pg $(100 \mathrm{nM})$ for indicated periods of time. In all experiments, FGFs were used together with heparin sulphate $(10 \mathrm{ng} / \mathrm{ml})$. When required, media were supplemented with an appropriate inhibitor: PD173074 $(100 \mathrm{nM})$, MG132 $(2 \mu \mathrm{M})$, leptomycin $\mathrm{B}(0.5 \mathrm{nM})$, FMK $(10 \mu \mathrm{M})$, U0126 $(10 \mu \mathrm{M})$, SB202190 $(10 \mu \mathrm{M})$ or SP600125 $(10 \mu \mathrm{M})$.

\section{Clinical data}

$\mathrm{BCa}$ primary tumour samples were obtained from 152 patients treated between 1999 and 2009 at the Medical University of Gdansk Hospital. Follow-up data were available in 147 cases. Clinicopathological characteristics of the cohort are summarized in Supplementary Table S1. ER/PR/HER2 status was determined by routine histopathological assessment. Serial $5 \mu \mathrm{m}$ paraffin sections of formalin-fixed blocks were processed for immunohistochemistry for FGFR2 (mouse anti-human; 1:600; Abnova \#H00002263-M01), RSK2 (rabbit antihuman; 1:200; Life Span BioSciences, \# LS-B7708) and phospho-RSK (RSK-P) (rabbit anti-human; 1:100, Sigma-Aldrich \#SAB4503961) using protocols recommended by the manufacturers. As a negative control for immunostaining, primary antibodies were replaced by non-immune sera. Scoring of immunostaining (not distinction was made between subcellular distributions) was carried out as follows: i) 0/negative - no reactivity or only faint reactivity in $<10 \%$ of tumour cells; ii) $1+$ / negative - faint reactivity in $\geq 10 \%$ of tumour cells; iii) $2+/$ positive - weak to moderate reactivity in $\geq 10 \%$ of tumour cells; iv) $3+/$ positive - strong reactivity in $\geq 10 \%$ of the tumour cells. Immunohistochemical staining was evaluated and scored independently by two observers (HMR and RK). The agreement on staining intensity was $>90 \%$. Where there was disagreement, intensity was determined by consensus. Final scores were dichotomized into: a) 'negative/low' for $0-1$ and b) 'positive/high' for $2-3$. The study was conducted in accordance with the Declaration of Helsinki and approved by the Local Research Ethics Committee of the Medical University of Gdansk (project licence \#118/2014/NKBBN).

\section{Statistical analyses}

All statistical analyses were performed using the STATISTICA software (version 10, StatSoft). Kendall's tau rank correlation test was used to study correlation between levels of PR, FGFR2, RSK2 and RSK-P in cancer 
tissue. Disease-free survival (DFS) was computed using Kaplan-Meier method and compared using log-rank test. Cox proportional hazards regression model was used to identify the independent predictors of DFS. Two-sided $p$ value $<0.05$ was considered as significant. All in vitro experiments were performed in triplicate unless otherwise indicated.

\section{ACKNOWLEDGMENTS}

We would like to thank Dr Jolanta Szade (Medical University in Gdansk) for preparation of pathological material, Dr Carol Lange and Dr Todd Knutson for sharing PR Ser294 antibodies (University of Minnesota). pWZL Neo Myr Flag RPSK6A3 plasmid was a gift from William Hahn \& Jean Zhao (Addgene plasmid \# 20627).

\section{CONFLICTS OF INTEREST}

The authors declare no conflicts of interest.

\section{GRANT SUPPORT}

This work was supported by National Science Centre: UMO-2012/06/M/NZ3/00023 (to RS), UMO2013/09/B/NZ4/02512 (to HR), UMO-2015/17/B/ NZ4/02157 (to RK) and UMO-2014/15/N/NZ3/04305 (to DC) grants.

\section{REFERENCES}

1. Kastner P, Krust A, Turcotte B, Stropp U, Tora L, Gronemeyer H, Chambon P. Two distinct estrogenregulated promoters generate transcripts encoding the two functionally different human progesterone receptor forms A and B. Embo j. 1990; 9:1603-1614.

2. Soyal S, Ismail PM, Li J, Mulac-Jericevic B, Conneely OM, Lydon JP. Progesterone's role in mammary gland development and tumorigenesis as disclosed by experimental mouse genetics. Breast Cancer Res. 2002; 4:191-196.

3. Lydon JP, DeMayo FJ, Funk CR, Mani SK, Hughes AR, Montgomery CA Jr, Shyamala G, Conneely OM, O’Malley BW. Mice lacking progesterone receptor exhibit pleiotropic reproductive abnormalities. Genes Dev. 1995; 9:2266-2278.

4. Graham JD, Clarke CL. Physiological action of progesterone in target tissues. Endocr Rev. 1997; 18:502-519.

5. Schairer C, Lubin J, Troisi R, Sturgeon S, Brinton L, Hoover R. Menopausal Estrogen and Estrogen-Progestin Replacement Therapy and Breast Cancer Risk. JAMA. 2015; 283:485-491.

6. Horwitz KB, McGuire WL. Predicting response to endocrine therapy in human breast cancer: a hypothesis. Science. 1975; 189:726-727.
7. Bardou VJ, Arpino G, Elledge RM, Osborne CK, Clark GM. Progesterone receptor status significantly improves outcome prediction over estrogen receptor status alone for adjuvant endocrine therapy in two large breast cancer databases. J Clin Oncol. 2003; 21:1973-1979.

8. Ravdin PM, Green S, Dorr TM, McGuire WL, Fabian C, Pugh RP, Carter RD, Rivkin SE, Borst JR, Belt RJ. Prognostic significance of progesterone receptor levels in estrogen receptor-positive patients with metastatic breast cancer treated with tamoxifen: results of a prospective Southwest Oncology Group study. J Clin Oncol. 1992; 10:1284-1291.

9. Elledge RM, Green S, Pugh R, Allred DC, Clark GM, Hill J, Ravdin P, Martino S, Osborne CK. Estrogen receptor (ER) and progesterone receptor (PgR), by ligand-binding assay compared with ER, PgR and $\mathrm{pS} 2$, by immunohistochemistry in predicting response to tamoxifen in metastatic breast cancer: a Southwest Oncology Group Study. Int J Cancer. 2000; 89:111-117.

10. Cui X, Schiff R, Arpino G, Osborne CK, Lee AV. Biology of progesterone receptor loss in breast cancer and its implications for endocrine therapy. J Clin Oncol. 2005; 23:7721-7735.

11. Cohen-Solal K, Bailly A, Rauch C, Quesne M, Milgrom E. Specific binding of progesterone receptor to progesteroneresponsive elements does not require prior dimerization. Eur J Biochem. 1993; 214:189-195.

12. Knutson TP, Lange CA. Tracking progesterone receptormediated actions in breast cancer. Pharmacol Ther. 2014; 142:114-125.

13. Fu XD, Giretti MS, Baldacci C, Garibaldi S, Flamini M, Sanchez AM, Gadducci A, Genazzani AR, Simoncini T. Extra-nuclear signaling of progesterone receptor to breast cancer cell movement and invasion through the actin cytoskeleton. PLoS One. 2008; 3:e2790.

14. Carnevale RP, Proietti CJ, Salatino M, Urtreger A, Peluffo G, Edwards DP, Boonyaratanakornkit V, Charreau EH, Bal de Kier Joffé E, Schillaci R, Elizalde PV. Progestin effects on breast cancer cell proliferation, proteases activation, and in vivo development of metastatic phenotype all depend on progesterone receptor capacity to activate cytoplasmic signaling pathways. Mol Endocrinol. 2007; 21:1335-1358.

15. Boonyaratanakornkit V, McGowan E, Sherman L, Mancini MA, Cheskis BJ, Edwards DP. The role of extranuclear signaling actions of progesterone receptor in mediating progesterone regulation of gene expression and the cell cycle. Mol Endocrinol. 2007; 21:359-375.

16. Daniel AR, Faivre EJ, Lange CA. Phosphorylationdependent antagonism of sumoylation derepresses progesterone receptor action in breast cancer cells. Mol Endocrinol. 2007; 21:2890-2906.

17. Daniel AR, Gaviglio AL, Czaplicki LM, Hillard CJ, Housa D, Lange CA. The progesterone receptor hinge region regulates the kinetics of transcriptional responses 
through acetylation, phosphorylation, and nuclear retention. Mol Endocrinol. 2010; 24:2126-2138.

18. Qiu M, Lange CA. MAP kinases couple multiple functions of human progesterone receptors: degradation, transcriptional synergy, and nuclear association. J Steroid Biochem Mol Biol. 2003; 85:147-157.

19. Kim HM, Jung WH, Koo JS. Expression of cancerassociated fibroblast related proteins in metastatic breast cancer: an immunohistochemical analysis. Journal of Translational Medicine. 2015; 13:222.

20. Saikali Z, Setya H, Singh G, Persad S. Role of IGF-1/IGF-1R in regulation of invasion in DU145 prostate cancer cells. Cancer Cell Int. 2008; 8:10.

21. Danielpour D. Functions and regulation of transforming growth factor-beta (TGF-beta) in the prostate. Eur J Cancer. 2005; 41:846-857.

22. Orimo A, Gupta PB, Sgroi DC, Arenzana-Seisdedos F, Delaunay T, Naeem R, Carey VJ, Richardson AL, Weinberg RA. Stromal fibroblasts present in invasive human breast carcinomas promote tumor growth and angiogenesis through elevated SDF-1/CXCL12 secretion. Cell. 2005; 121:335-348.

23. Giulianelli S, Cerliani JP, Lamb CA, Fabris VT, Bottino MC, Gorostiaga MA, Novaro V, Gongora A, Baldi A, Molinolo A, Lanari C. Carcinoma-associated fibroblasts activate progesterone receptors and induce hormone independent mammary tumor growth: A role for the FGF-2/ FGFR-2 axis. Int J Cancer. 2008; 123:2518-2531.

24. Cui X, Zhang P, Deng W, Oesterreich S, Lu Y, Mills GB, Lee AV. Insulin-like growth factor-I inhibits progesterone receptor expression in breast cancer cells via the phosphatidylinositol 3-kinase/Akt/mammalian target of rapamycin pathway: progesterone receptor as a potential indicator of growth factor activity in breast cancer. Mol Endocrinol. 2003; 17:575-588.

25. Cerliani JP, Guillardoy T, Giulianelli S, Vaque JP, Gutkind JS, Vanzulli SI, Martins R, Zeitlin E, Lamb CA, Lanari C. Interaction between FGFR-2, STAT5, and progesterone receptors in breast cancer. Cancer Res. 2011; 71:3720-3731.

26. Faivre EJ, Lange CA. Progesterone receptors upregulate Wnt-1 to induce epidermal growth factor receptor transactivation and c-Src-dependent sustained activation of Erk1/2 mitogen-activated protein kinase in breast cancer cells. Mol Cell Biol. 2007; 27:466-480.

27. Dressing GE, Hagan CR, Knutson TP, Daniel AR, Lange CA. Progesterone receptors act as sensors for mitogenic protein kinases in breast cancer models. Endocr Relat Cancer. 2009; 16:351-361.

28. Qiu M, Olsen A, Faivre E, Horwitz KB, Lange CA. Mitogen-activated protein kinase regulates nuclear association of human progesterone receptors. Mol Endocrinol. 2003; 17:628-642.

29. Shen T, Horwitz KB, Lange CA. Transcriptional hyperactivity of human progesterone receptors is coupled to their ligand-dependent down-regulation by mitogenactivated protein kinase-dependent phosphorylation of serine 294. Mol Cell Biol. 2001; 21:6122-6131.

30. Czaplinska D, Mieczkowski K, Supernat A, Skladanowski AC, Kordek R, Biernat W, Zaczek AJ, Romanska HM, Sadej R. Interactions between FGFR2 and RSK2-implications for breast cancer prognosis. Tumour Biol. 2016.

31. Balana ME, Lupu R, Labriola L, Charreau EH, Elizalde PV. Interactions between progestins and heregulin (HRG) signaling pathways: HRG acts as mediator of progestins proliferative effects in mouse mammary adenocarcinomas. Oncogene. 1999; 18:6370-6379.

32. Palmieri C, Roberts-Clark D, Assadi-Sabet A, Coope RC, O'Hare M, Sunters A, Hanby A, Slade MJ, Gomm JJ, Lam EW, Coombes RC. Fibroblast growth factor 7, secreted by breast fibroblasts, is an interleukin-1betainduced paracrine growth factor for human breast cells. J Endocrinol. 2003; 177:65-81.

33. Imagawa W, Cunha GR, Young P, Nandi S. Keratinocyte growth factor and acidic fibroblast growth factor are mitogens for primary cultures of mammary epithelium. Biochem Biophys Res Commun. 1994; 204:1165-1169.

34. Ulich TR, Yi ES, Cardiff R, Yin S, Bikhazi N, Biltz R, Morris CF, Pierce GF. Keratinocyte growth factor is a growth factor for mammary epithelium in vivo. The mammary epithelium of lactating rats is resistant to the proliferative action of keratinocyte growth factor. Am J Pathol. 1994; 144:862-868.

35. Bansal R, Magge S, Winkler S. Specific inhibitor of FGF receptor signaling: FGF-2-mediated effects on proliferation, differentiation, and MAPK activation are inhibited by PD173074 in oligodendrocyte-lineage cells. J Neurosci Res. 2003; 74:486-493.

36. Pardo OE, Latigo J, Jeffery RE, Nye E, Poulsom R, Spencer-Dene B, Lemoine NR, Stamp GW, Aboagye EO, Seckl MJ. The fibroblast growth factor receptor inhibitor PD173074 blocks small cell lung cancer growth in vitro and in vivo. Cancer Res. 2009; 69:8645-8651.

37. Wesche J, Haglund K, Haugsten EM. Fibroblast growth factors and their receptors in cancer. Biochem J. 2011; 437:199-213.

38. Zhang $\mathrm{X}$, Ibrahimi OA, Olsen SK, Umemori $\mathrm{H}$, Mohammadi M, Ornitz DM. Receptor specificity of the fibroblast growth factor family. The complete mammalian FGF family. J Biol Chem. 2006; 281:15694-15700.

39. Byron SA, Gartside MG, Wellens CL, Mallon MA, Keenan JB, Powell MA, Goodfellow PJ, Pollock PM. Inhibition of activated fibroblast growth factor receptor 2 in endometrial cancer cells induces cell death despite PTEN abrogation. Cancer Res. 2008; 68:6902-6907.

40. Lange CA. Making sense of cross-talk between steroid hormone receptors and intracellular signaling pathways: who will have the last word? Mol Endocrinol. 2004; 18:269-278. 
41. Lange CA, Richer JK, Shen T, Horwitz KB. Convergence of progesterone and epidermal growth factor signaling in breast cancer. Potentiation of mitogen-activated protein kinase pathways. J Biol Chem. 1998; 273:31308-31316.

42. Knutson TP, Daniel AR, Fan D, Silverstein KA, Covington KR, Fuqua SA, Lange CA. Phosphorylated and sumoylation-deficient progesterone receptors drive proliferative gene signatures during breast cancer progression. Breast Cancer Res. 2012; 14:R95.

43. Lange CA, Shen T, Horwitz KB. Phosphorylation of human progesterone receptors at serine-294 by mitogenactivated protein kinase signals their degradation by the $26 \mathrm{~S}$ proteasome. Proc Natl Acad Sci USA. 2000; 97:1032-1037.

44. Calvo V, Beato M. BRCA1 counteracts progesterone action by ubiquitination leading to progesterone receptor degradation and epigenetic silencing of target promoters. Cancer Res. 2011; 71:3422-3431.

45. Daniel AR, Hagan CR, Lange CA. Progesterone receptor action: defining a role in breast cancer. Expert Rev Endocrinol Metab. 2011; 6:359-369.

46. Han YH, Moon HJ, You BR, Park WH. The effect of MG132, a proteasome inhibitor on HeLa cells in relation to cell growth, reactive oxygen species and GSH. Oncol Rep. 2009; 22:215-221.

47. Wolff B, Sanglier JJ, Wang Y. Leptomycin B is an inhibitor of nuclear export: inhibition of nucleo-cytoplasmic translocation of the human immunodeficiency virus type 1 (HIV-1) Rev protein and Rev-dependent mRNA. Chem Biol. 1997; 4:139-147.

48. Labriola L, Salatino M, Proietti CJ, Pecci A, Coso OA, Kornblihtt AR, Charreau EH, Elizalde PV. Heregulin induces transcriptional activation of the progesterone receptor by a mechanism that requires functional ErbB-2 and mitogen-activated protein kinase activation in breast cancer cells. Mol Cell Biol. 2003; 23:1095-1111.

49. Kim HJ, Cui X, Hilsenbeck SG, Lee AV. Progesterone receptor loss correlates with human epidermal growth factor receptor 2 overexpression in estrogen receptor-positive breast cancer. Clin Cancer Res. 2006; 12:1013s-1018s.

50. Czaplinska D, Turczyk L, Grudowska A, Mieszkowska M, Lipinska AD, Skladanowski AC, Zaczek AJ, Romanska HM, Sadej R. Phosphorylation of RSK2 at Tyr529 by FGFR2-p38 enhances human mammary epithelial cells migration. Biochim Biophys Acta. 2014; 1843:2461-2470.

51. Richards SA, Dreisbach VC, Murphy LO, Blenis J. Characterization of regulatory events associated with membrane targeting of $\mathrm{p} 90$ ribosomal S6 kinase 1. Mol Cell Biol. 2001; 21:7470-7480.

52. Boehm JS, Zhao JJ, Yao J, Kim SY, Firestein R, Dunn IF, Sjostrom SK, Garraway LA, Weremowicz S, Richardson AL, Greulich H, Stewart CJ, Mulvey LA, et al.
Integrative genomic approaches identify IKBKE as a breast cancer oncogene. Cell. 2007; 129:1065-1079.

53. Woo DD, Fay SP, Griest R, Coty W, Goldfine I, Fox CF. Differential phosphorylation of the progesterone receptor by insulin, epidermal growth factor, and platelet-derived growth factor receptor tyrosine protein kinases. J Biol Chem. 1986; 261:460-467.

54. Hunter DJ, Kraft P, Jacobs KB, Cox DG, Yeager M, Hankinson SE, Wacholder S, Wang Z, Welch R, Hutchinson A, Wang J, Yu K, Chatterjee N, et al. A genome-wide association study identifies alleles in FGFR2 associated with risk of sporadic postmenopausal breast cancer. Nat Genet. 2007; 39:870-874.

55. Daniel AR, Qiu M, Faivre EJ, Ostrander JH, Skildum A, Lange CA. Linkage of progestin and epidermal growth factor signaling: phosphorylation of progesterone receptors mediates transcriptional hypersensitivity and increased ligand-independent breast cancer cell growth. Steroids. 2007; 72:188-201.

56. Vicent GP, Ballare C, Nacht AS, Clausell J, SubtilRodriguez A, Quiles I, Jordan A, Beato M. Induction of progesterone target genes requires activation of Erk and Msk kinases and phosphorylation of histone H3. Mol Cell. 2006; 24:367-381.

57. Zaru R, Ronkina N, Gaestel M, Arthur JS, Watts C. The MAPK-activated kinase Rsk controls an acute Tolllike receptor signaling response in dendritic cells and is activated through two distinct pathways. Nat Immunol. 2007; 8:1227-1235.

58. Eisinger-Mathason TS, Andrade J, Lannigan DA. RSK in tumorigenesis: connections to steroid signaling. Steroids. 2010; 75:191-202.

59. Markiewicz A, Książkiewicz M, Wełnicka-Jaśkiewicz M, Seroczyńska B, Skokowski J, Szade J, Żaczek AJ. Mesenchymal phenotype of CTC-enriched blood fraction and lymph node metastasis formation potential. PLoS One. 2014; 9:e93901.

60. Sadej R, Skladanowski AC. Dual, enzymatic and nonenzymatic, function of ecto-5'-nucleotidase (eN, CD73) in migration and invasion of A375 melanoma cells. Acta Biochim Pol. 2012; 59:647-652.

61. Dutt A, Salvesen HB, Chen TH, Ramos AH, Onofrio RC, Hatton C, Nicoletti R, Winckler W, Grewal R, Hanna M, Wyhs N, Ziaugra L, Richter DJ, et al. Drug-sensitive FGFR2 mutations in endometrial carcinoma. Proc Natl Acad Sci U S A. 2008; 105:8713-8717.

62. Shahbazian D, Roux PP, Mieulet V, Cohen MS, Raught B, Taunton J, Hershey JW, Blenis J, Pende M, Sonenberg N. The $\mathrm{mTOR} / \mathrm{PI} 3 \mathrm{~K}$ and MAPK pathways converge on eIF4B to control its phosphorylation and activity. EMBO J. 2006; 25:2781-2791. 